\title{
The effect of mixtures on colonisation of leaf litter decomposing in a stream and at its riparian zone
}

\author{
M. Abelho \\ Instituto Politécnico de Coimbra, Escola Superior Agrária, Bencanta, 3045-601 Coimbra, Portugal \\ Centre for Functional Ecology, CFE, Universidade de Coimbra, Apartado 3046, 3001-401 Coimbra, Portugal \\ Correspondence to: M. Abelho (abelho@esac.pt)
}

Received: 8 January 2014 - Revised: 4 April 2014 - Accepted: 29 April 2014 - Published: 3 June 2014

\begin{abstract}
The effect of mixing litter on decomposition and colonisation has been the focus of many studies carried independently in terrestrial and aquatic ecosystems. Those studies are carried out in different regions, use different experimental protocols and methodologies for the assessment of additive or non-additive effects, and the conclusions on the effect of mixtures vary accordingly. In this study I tested the hypothesis, via a short-term decomposition experiment, that, when using the same experimental protocol, mixtures have similar additive effects on decomposition and associated biota in a stream and at its riparian zone. The effect of mixing litter was assessed by comparing values in mixtures with the average of single species, alder and poplar (method 1); comparing the value of a species in mixture with the value of that species alone (method 2); and by a graphical analysis of the average difference between observed and expected values and the $95 \%$ confidence intervals (method 3). Method 1 was the most conservative, detecting non-additive effects on macroinvertebrate abundance only; method 2 detected non-additive effects on both dry mass remaining and ergosterol, with differential responses of the leaf species and the habitat; and method 3 detected non-additive effects on all variables except ergosterol and percentage detritivore abundance and also identified different responses of the leaves exposed in the terrestrial and the aquatic habitats. These results show that (i) the methodology used to detect the effects of mixtures deeply influences the results obtained, and may partially explain the diversity of responses available in literature; and (ii) the effect of mixtures may differ in the stream and at the riparian area. However, the findings of the present work should be assessed in a larger-scale experiment in order to generalise the effects of mixing litter on terrestrial and aquatic habitats.
\end{abstract}

\section{Introduction}

Riparian zones are recognised as a key feature in stream ecology, due to the effect of shading on water temperature, photosynthesis inhibition and as a source of detritus as the main food resource for the aquatic food webs (Naiman and Décamps, 1997; Cummins, 2002). Riparian zones are also considered to play an important and significant role in terrestrial ecology, due to their effect in the cycling of nutrients (Fior et al., 2010). For instance, $N$ retention in the vegetation and litter compartment may contribute up to $99 \%$ of the total $N$ removed from the water flowing through the riparian zone (Hefting et al., 2005).
Breakdown rates on the riparian zone depend on moisture (Hutchens Jr. and Wallace, 2002) and soil microbial and faunal communities (Edmonds and Tuttle, 2010; Hunter et al., 2003), and tend to slow with distance from stream (Hutchens Jr. and Wallace, 2002). Both in stream and at the forest floor fungi are the key microbial decomposers whose activities are modified and complemented by litter-consuming detritivores (Gessner et al., 2010), but leaves of a given species consistently show slower riparian than stream decomposition rates, with stream rates 3.9 to 18.8 times faster than riparian rates, depending on the exposure habitat (surface or subsurface) and on species (Arizpe et al., 2008; Harner et al., 2009; Hutchens Jr. and Wallace, 2002). This is due to terrestrial moisture limitation and to the more efficient stream 
invertebrate detritivores, which can consume ten times more litter than terrestrial ones (Gessner et al., 2010), despite the higher number of efficient lignin-degrader fungal species involved in leaf decomposition in forest floors (Gessner et al., 2010).

Litter-mixing experiments predominantly result in nonadditive effects, with synergistic dominating over antagonistic responses in both terrestrial and aquatic ecosystems (Hättenschwiler et al., 2005; Lecerf et al., 2007). Potential mechanisms for the frequently observed litter-diversity effects on mass loss and nitrogen dynamics include fungi-driven nutrient transfer among litter species, inhibition or stimulation of microorganisms by specific litter compounds, and positive feedback of fauna due to greater habitat and food diversity (Kominoski et al., 2009; Naiman and Décamps, 1997). Research on the effect of mixtures varies largely in experimental protocols and the methodology used to assess the existence of non-additive effects (Gartner and Cardon, 2004; Hättenschwiler et al., 2005). Thus, in addition to the mechanisms explaining additive or non-additive responses, nonstandardised methodologies may have also contributed to the variety of responses available in literature. Moreover, experiments have developed largely independently in forest floors and aquatic ecosystems (Hättenschwiler et al., 2005; Lecerf et al., 2009); precluding a general ecological understanding on the effect of mixtures. Although both systems rely on leaf litter decomposition as their main energy source, limitations to decomposer activities due to abiotic factors such as water and nutrient availability, as well as detritivore feeding strategies differ (Gessner et al., 2010), and may differentially influence the effect of mixing litter in the terrestrial and the aquatic habitats.

The objective of this study was to test the hypothesis that, under the same experimental protocol, the effect of mixtures is similar in stream and at the riparian area. For that purpose I compared breakdown and colonisation by fungi and invertebrates of leaf litter of common alder (Alnus glutinosa (L.) Gaertner), hybrid black poplar (Populus $x$ canadensis Moench), and a 1:1 mixture of both species in a stream and at its riparian area.

\section{Methods}

\subsection{Study site}

The experiment was carried out at Ribeira do Botão, a 3rd order stream located near Coimbra, central Portugal $\left(40^{\circ} 18^{\prime} 23^{\prime \prime} \mathrm{N}, 08^{\circ} 23^{\prime} 55^{\prime \prime} \mathrm{W}\right.$; elevation $80 \mathrm{~m}$ ), during November 2011 . The stream drains a sedimentary rock (mostly limestone) basin dominated by eucalypt forestry with small-scale agricultural fields downstream of the study site. The riparian vegetation at the study site was composed of mixed deciduous trees where common alder was dominant. By the beginning of the experiment leaves (mainly alder leaf litter) were already accumulating on the floor. During the study period (data collected at the nearest meteorological station located at $40^{\circ} 12^{\prime} 33^{\prime \prime} \mathrm{N}, 08^{\circ} 27^{\prime} 08^{\prime \prime} \mathrm{W}$; elevation $16 \mathrm{~m}$ ), average daily air temperature was $12.6^{\circ} \mathrm{C}$ (range $8.6-18.1^{\circ} \mathrm{C}$ ), precipitation totalled $168 \mathrm{~mm}$ and humidity was $85.8 \%$ (range 54.0 $96.4 \%$ ). At the stream bank where the bags were deployed (circa $1.5 \mathrm{~m}$ above the stream surface and $1 \mathrm{~m}$ away from the stream margin), fallen leaf litter was moist throughout the experiment due to precipitation (personal observation) and no surface hydrologic interaction occurred between the stream and the riparian litter bag location. The stream channel was 3.1 to $3.4 \mathrm{~m}$ wide, had a water depth of 13.6 to $16.0 \mathrm{~cm}$, current velocity of 0.239 to $0.307 \mathrm{~m} \mathrm{~s}^{-1}$ and discharge of 0.107 to $0.140 \mathrm{~m}^{3} \mathrm{~s}^{-1}$. The water temperature was 9.6 to $13.3^{\circ} \mathrm{C}$, pH 7.1 to 7.3 , conductivity $171 \mu \mathrm{S} \mathrm{cm}^{-1}$ and dissolved oxygen $11.9 \mathrm{mg} \mathrm{L}^{-1}$.

\subsection{Experiment}

Decomposition was studied on leaves of common alder ( $A l$ nus glutinosa (L.) Gaertner) and hybrid black poplar (Populus $x$ canadensis Moench). These two species were chosen because the genera are well known, with data available in literature, and common in riparian zones across broad geographic areas. Senescent leaves were collected from the trees or from the ground when freshly fallen, during three consecutive days on October 2011, air-dried in the laboratory and weighed to the nearest $0.001 \mathrm{~g}$ to form single species or mixture $(1: 1)$ portions of $2.8 \mathrm{~g} \pm 0.08 \mathrm{~g}$ SE. The leaves were introduced in $5 \mathrm{~mm}$ mesh square bags $(20 \mathrm{~cm} \times 20 \mathrm{~cm})$, tied in groups ( 1 alder, 1 mixture, 1 poplar) and placed at the riparian zone by the stream channel and in a riffle area of the stream on 2 November 2011. The riparian bags were deployed on the floor and loosely covered with dead fallen leaves. The stream bags were tied to nails fixed at the bottom of the stream.

On each sampling occasion (after 14 and 28 days), three replicate bags of each type were randomly removed, allocated to individual plastic bags and transported to the laboratory in an ice chest. In the laboratory, the bags were opened and the leaves gently washed with tap water through a $0.5 \mathrm{~mm}$ mesh sieve to remove attached debris and invertebrates. The invertebrates were stored in $75 \%$ ethanol for a maximum period of a week, identified and counted under a binocular magnifier, assigned to detritivores or others (Hopkin, 2002; Quigley and Madge, 1988; Tachet et al., 2000), oven-dried $\left(60^{\circ} \mathrm{C}, 3\right.$ days $)$ and combusted $\left(500^{\circ} \mathrm{C}, 5 \mathrm{~h}\right)$ to determine ash-free dry mass (AFDM). Although preservation in ethanol may alter AFDM of the invertebrates (Leuven et al., 1985), the short preservation period and the dark conditions of storage may have been sufficient to keep losses to a minimum and allow meaningful comparisons among samples.

From each sample a group of six $1.4 \mathrm{~mm}$ leaf discs was cut with a cork borer and immediately frozen at $-20^{\circ} \mathrm{C}$ to determine ergosterol as a surrogate for fungal biomass 
(Newell, 1992). The rest of the leaves of each species was oven-dried $\left(60^{\circ} \mathrm{C}, 3\right.$ days) and weighed separately to determine dry mass. Dry mass remaining of each species on each sampling date was the sum of the mass of the leaves and the mass of the discs. Species in mixtures were assessed individually and summed to obtain mass remaining of the mixture. Initial oven-dry mass of the leaves was estimated from the ratio oven-dry to air-dry mass of an extra set of three leaf portions per leaf species.

\subsection{Ergosterol analysis}

Ergosterol is a membrane-bound sterol in most fungi, is absent from vascular plants, and is the most used indicator of fungal biomass associated with decomposing leaves in both terrestrial and aquatic habitats where light is a limiting factor (Gessner, 2005). Ergosterol was extracted with a microwave assisted method (MEA) based on that of Young (1995). The discs were lyophilized overnight, immediately weighed to determine dry mass, transferred to a $30 \mathrm{~mL}$ glass vial containing $2.0 \mathrm{~mL}$ of methanol $\left(\mathrm{CH}_{4} \mathrm{O}\right)$ and $0.5 \mathrm{~mL}$ of $2 \mathrm{M}$ of aqueous sodium hydroxide $(\mathrm{NaOH})$, and tightly sealed with a Teflon-lined screw cap. The vials were individually placed in $300 \mathrm{~mL}$ capped plastic bottles and tightly sealed. Eleven of these combinations were placed in a domestic microwave oven (operating at $2450 \mathrm{MHz}$ and $750 \mathrm{~W}$ maximum output), heated at $50 \%$ power for three periods of $20 \mathrm{~s}$ with $3 \mathrm{~min}$ intervals and removed from the plastic bottle after cooling to room temperature (circa $15 \mathrm{~min}$ ). The solution was neutralised with $1 \mathrm{~mL}$ of $1 \mathrm{M}$ of aqueous hydrochloric acid $(\mathrm{HCl})$ and ergosterol was extracted with three consecutive $2 \mathrm{~mL}$ methanol and pentane $\left(\mathrm{C}_{5} \mathrm{H}_{12}\right)$ washes; after vorticity the supernatant was removed with individual Pasteur pipettes to $10 \mathrm{~mL}$ glass tubes. The pentane extracts were evaporated to dryness on a moist sand bath at $55^{\circ} \mathrm{C}$, rinsed three times with $0.5 \mathrm{~mL}$ of pentane to an HPLC vial, evaporated again and the residue was dissolved in $1 \mathrm{~mL}$ of methanol and kept at $4{ }^{\circ} \mathrm{C}$ in the dark until analysis. Recovery rate of ergosterol for each extraction run was estimated with a blank sample spiked with a known amount of ergosterol and treated as the other samples. Ergosterol was quantified by measuring absorbance at $282 \mathrm{~nm}$ after separation from other lipids by HPLC (Dionex, Sunnyvale, California) with column (LiChroCART 250-4 LiChrospher 100 RP-18 (5 mm), Merck, Darmstadt, Germany) temperature maintained at $33^{\circ} \mathrm{C}$ and a mobile phase of pure methanol at a flow rate of $1.4 \mathrm{~mL} \mathrm{~min}^{-1}$ (Gessner, 2005). Peak identity was checked on the basis of retention times of pure ergosterol standards and quantification was achieved by measuring peak height (Gessner and Chauvet, 1997). Ergosterol was expressed as $\mathrm{mg} \mathrm{g}^{-1}$ leaf dry mass on basis of the dry mass of the discs. Ergosterol content of mixtures was the average of the value of each species.

\subsection{Statistical analysis}

Exponential breakdown rates were calculated as the slope of the regression of the natural logarithm of percentage dry mass remaining upon time in days. Analysis of covariance (ANCOVA; Zar, 1996) was used to test the effect of location and treatment on the slope (breakdown rate) of the regressions. Percentage dry mass remaining, invertebrate and ergosterol data were tested for homogeneity of variances (Bartlett's test; Zar, 1996) before testing the effect of location (riparian vs. stream) and treatment (alder vs. poplar vs. mixture) with repeated-measures ANOVA using time as the within-subjects variable (Zar, 1996). Whenever significant differences among species were found, post hoc Tukey type tests were carried out to determine identity of the differences (Zar, 1996). Statistical analysis was carried out with the software STATISTICA 7 with the level of significance set at $\alpha=0.05$.

All percentages and the abundance of invertebrates were homoscedastic $(B<15.89, \mathrm{~d} f=8-10, p>0.1)$ while invertebrate biomass and ergosterol concentrations were heteroscedastic $(B>22.3, \mathrm{~d} f=10, p<0.01)$, and were transformed with the logarithmic transformation $X^{\prime}=\ln (X+1)$ (Zar, 1996), becoming homoscedastic $(B<17.4, \mathrm{~d} f=10$, $p>0.07)$.

\subsection{Detecting additive or non-additive responses}

Three methods were used to determine whether tested variables showed additive or non-additive responses to mixtures. In method 1, values of the response variables in mixtures (observed) were compared with values calculated by averaging single-species treatments (expected) by repeated-measures ANOVA as above (treatment being observed and expected values). If no significant differences between observed and expected values were detected, mixtures were considered additive for that variable. If non-additive, the direction of the difference indicated synergistic (observed $>$ expected) or inhibition (observed < expected) effects of that variable in the mixture. The previous approach may mask species-specific responses to mixing litter (Hättenschwiler et al., 2005); thus, method 2 compared the value of a species in mixture with the value of that species alone by two-way repeatedmeasures ANOVA as above (treatment being species in mixture and single species) and was used only for percentage dry mass remaining and ergosterol concentrations. The existence of significant differences was considered an indication of non-additive effects: synergistic if the value in mixture was higher than the value alone or antagonistic if otherwise. In methods 1 and 2, a significant interaction between location and treatment was indicative of a differential effect of the mixtures in the stream and at the riparian zone. Method 3 consisted in the graphical analysis described by Ball et al. (2008). For each response variable, the difference between observed and expected values of the replicates was computed 
Table 1. Exponential breakdown rates $\left(-k\right.$ day $^{-1} \pm 95 \%$ confidence limits) of leaves of alder, poplar and mixture, of alder and poplar in mixture, and calculated on basis of the average of singlespecies treatments, decomposing in the stream and at the riparian zone of Ribeira do Botão. $N=9$, except for alder in stream where $N=8 ; r^{2} \geq 0.85, p<0.0001$.

\begin{tabular}{lcc}
\hline Treatment & Riparian & Stream \\
\hline Alder & $0.0187 \pm 0.0039$ & $0.0430 \pm 0.0011$ \\
Poplar & $0.0091 \pm 0.0034$ & $0.0220 \pm 0.0060$ \\
Mixture & $0.0146 \pm 0.0033$ & $0.0342 \pm 0.0040$ \\
Alder in mixture & $0.0219 \pm 0.0050$ & $0.0458 \pm 0.0059$ \\
Poplar in mixture & $0.0145 \pm 0.0052$ & $0.0316 \pm 0.0062$ \\
Average of single species & $0.0136 \pm 0.0032$ & $0.0310 \pm 0.0040$ \\
\hline
\end{tabular}

as $100 \times($ observed - expected $) /$ expected $)$, and the average and the $95 \%$ confidence intervals (CI) were taken for each treatment and location $(n=6)$. The effect was considered non-additive if the CI did not cross $y=0$ for each point, indicating synergistic, if the difference was positive or antagonistic effects, if the difference was negative, and otherwise considered additive. All heteroscedastic variables (after Bartley's test) were transformed as above.

\section{Results}

\subsection{Mass loss, fungal and invertebrate colonisation}

All regressions of dry mass remaining upon time were significant and fitted to the negative exponential model $\left(r^{2} \geq 0.85\right.$; $p<0.0001$; Table 1). Breakdown rates were faster in the stream than at the riparian area $\left(F_{1,46}=30.8, p<0.0001\right)$ and there was a significant effect of treatment $\left(F_{2,46}=3.9\right.$, $p<0.05)$ with poplar decomposing slower than alder or the mixtures $(p<0.05)$. After 28 days, leaves at the riparian zone had lost $23 \%$ (poplar) to $41 \%$ (alder) while leaves in the stream lost $46 \%$ (poplar) to $70 \%$ (alder) of initial mass (Fig. 1a). Both location $\left(F_{1,15}=179.1, p<0.0001\right.$; riparian $>$ stream $)$ and treatment $\left(F_{2,15}=20.2, p<0.0001\right.$; poplar $>$ mixture $=$ alder, $p<0.01)$ had a significant effect on dry mass remaining.

Ergosterol concentrations associated with decomposing leaves attained higher values and showed higher variation in the stream than at the riparian zone (Fig. 1b). There was a significant effect of location $\left(F_{1,15}=189.5\right.$, $p<0.0001$; stream $>$ riparian $)$ and treatment $\left(F_{2,15}=12.5\right.$, $p<0.001$; poplar $<$ mixture $=$ alder, $p<0.05$ and $p<0.001$, respectively) on ergosterol concentrations associated with leaf litter.

Total invertebrate biomass (Fig. 2a) colonising the leaves was higher in the stream than at the riparian zone $\left(F_{1,15}=\right.$ 30.2, $p<0.0001)$ but there were no significant differences among treatments $\left(F_{2,15}=1.3, p=0.30\right)$. There was a significant effect of location $\left(F_{1,15}=0.7, p=0.40\right.$;

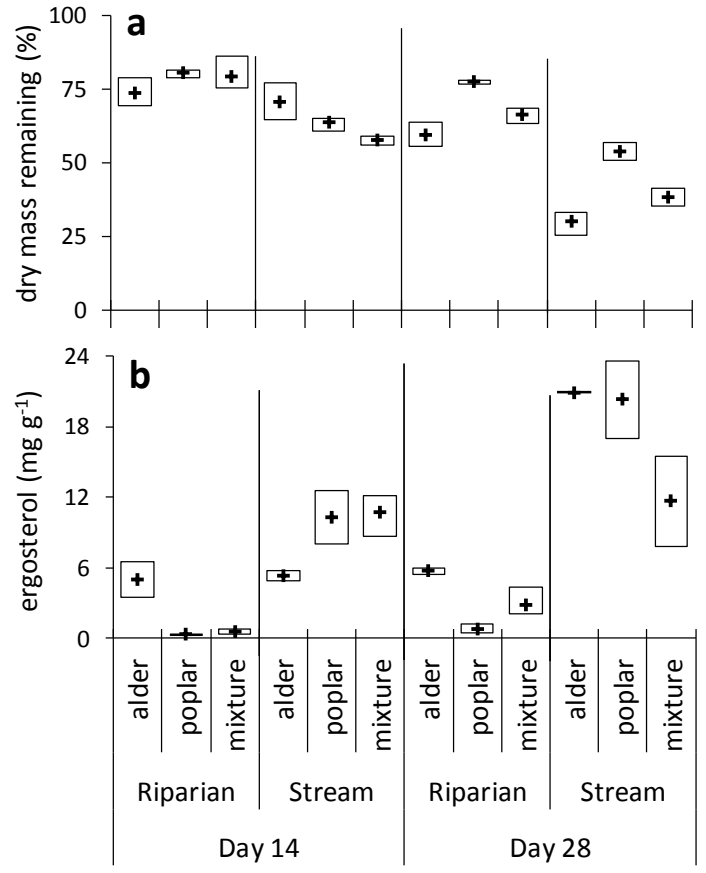

Figure 1. (a) Dry mass remaining and (b) ergosterol concentrations of leaves of alder, poplar and mixture decomposing in the stream and at the riparian zone of Ribeira do Botão. Values are ranges (boxes) and means $(+)$ of $n=3$.

stream $>$ riparian $)$ and treatment $\left(F_{2,15}=9.9, p<0.01\right)$ on total invertebrate abundance (Fig. 2b), with higher colonisation of mixtures than of poplar $(p<0.05)$. The percentage biomass of detritivores (Fig. 2c) was highly variable with no clear pattern regarding location $\left(F_{1,15}=0.7, p=0.40\right)$ or treatment $\left(F_{2,15}=0.8, p=0.47\right)$, while their percentage abundance (Fig. 2d) was affected by location $\left(F_{1,15}=12.4\right.$, $p<0.01$; stream $>$ riparian $)$ but not by treatment $\left(F_{2,15}=\right.$ 2.0, $p=0.09$ ).

The most abundant taxonomic groups at the riparian zone (Table 2), constituting $69 \%$ of total abundance were order Collembola $(20 \%$ in alder, $46 \%$ in poplar and $41 \%$ in mixture), order Diptera (49\% in alder, $29 \%$ in poplar and $24 \%$ in mixture), and Class Gastropoda (10\% in alder, $11 \%$ in poplar and $9 \%$ in mixture). The relative abundances of these taxonomic groups varied among treatments and with time, especially in alder leaves (Fig. 3a). The most abundant taxonomic groups in the stream (Table 2), constituting $94 \%$ of all abundance were order Plecoptera (family Leuctridae: $63 \%$ in alder, $64 \%$ in poplar and $68 \%$ in mixture), order Diptera (17\% in alder, $26 \%$ in poplar and $20 \%$ in mixture, of which the most abundant were family Simuliidae, $12 \%$ of total and Chironomidae, $7 \%$ ), and order Trichoptera (6\% in alder, $5 \%$ in poplar and $6 \%$ in mixture, of which the most abundant was family Hydropsychidae, with $4 \%$ of total). The relative abundances of these taxa were consistent through time and among treatments (Fig. 3b). 

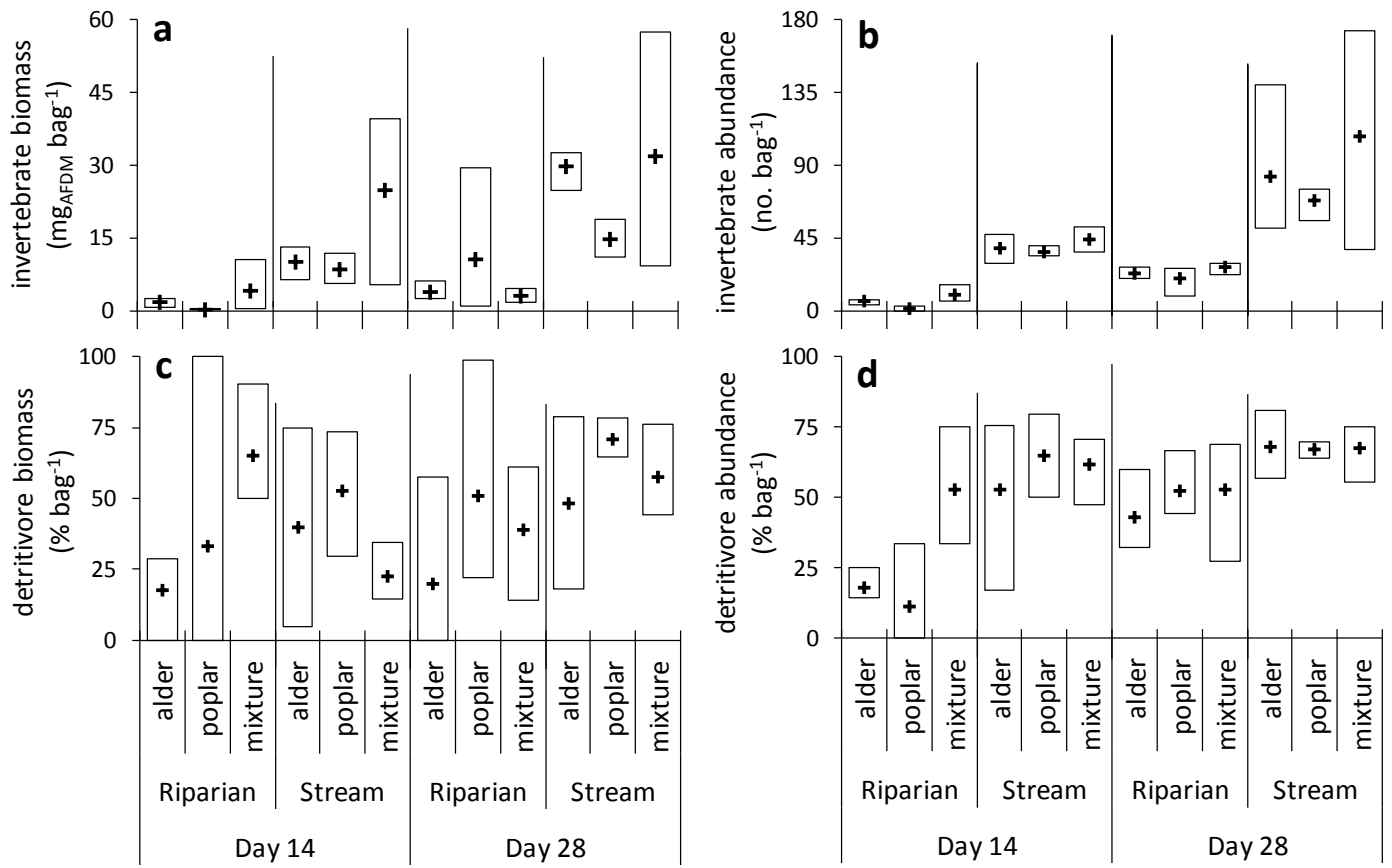

Figure 2. (a) Total invertebrate biomass and (b) abundance, (c) percentage detritivore biomass and (d) abundance colonising leaves of alder, poplar and mixture decomposing in the stream and at the riparian zone of Ribeira do Botão. Values are ranges (boxes) and means $(+)$ of $n=3$.

\subsection{The effect of mixtures}

When data were analysed with method 1 (comparing observed and expected values by two-way repeated-measures ANOVA), observed values were similar to expected for all variables $\left(F_{1,13}<4.2, p>0.06\right)$ except for invertebrate abundance $\left(F_{1,13}=9.9, p<0.01\right)$, which was higher than expected. There was no significant interaction between location and treatment for any of the tested variables $\left(F_{1,13}<2.9\right.$, $p>0.11)$.

When data were analysed with method 2 (comparing species in mixture with species alone), dry mass remaining and ergosterol concentrations of alder $\left(F_{1,10}=10.6, p<0.01\right.$ and $F_{1,10}=9.0, p<0.05$, respectively) and poplar leaves $\left(F_{1,13}=22.6, p<0.001\right.$ and $F_{1,13}=13.1, p<0.01$, respectively) were lower in the species in mixture than in the species alone. There was no significant interaction between location and treatment for dry mass of alder $\left(F_{1,10}=0.5\right.$, $p=0.48)$ or poplar $\left(F_{1,13}=0.9, p=0.35\right)$ or ergosterol of alder $\left(F_{1,10}=0.03, p=0.87\right)$. Ergosterol concentrations of poplar in the stream were higher when in mixture, whereas at the riparian zone they were higher when alone, resulting in a significant interaction between location and treatment $\left(F_{1,13}=35.7, p<0.0001\right)$.

When data were analysed with method 3 (comparing observed and expected values by graphical analysis), mixtures were additive for ergosterol and percentage detritivore abundance; all other variables showed non-additive effects either in the stream, at the riparian zone, or both (Fig. 4). Percent- age dry mass remaining of mixtures was additive at the riparian zone and non-additive, indicating synergistic effects on decomposition, in the stream (Fig. 4a). Invertebrate abundance and percentage detritivore biomass were additive in the stream and non-additive at the riparian zone, showing synergistic effects (Fig. 4b). Invertebrate biomass was nonadditive, showing synergistic effects in the stream and antagonistic effects at the riparian zone (Fig. 4a).

\section{Discussion}

\subsection{Mass loss and colonisation}

Breakdown rates are influenced by microbial biomass and activity which in turn are affected by abiotic factors such as temperature and water availability. Moisture availability was probably one factor contributing to the lower fungal biomass attained at the riparian zone in contrast to the stream (Gessner et al., 2010). Harner et al. (2009) also found higher fungal biomass in leaves exposed in the stream than at the surface of the riparian zone, but only in more recalcitrant rather than in more labile leaf litter. More detritivores colonised the leaves in the stream than at the riparian zone, further contributing to the faster instream rates (Hutchens Jr. and Wallace, 2002) especially if the stream detritivores consumed more litter per unit body mass than the terrestrial ones (Gessner et al., 2010). However, it was probably the difference in invertebrate community and functional structure that most contributed to the different breakdown rates in the stream and at the riparian 
Table 2. Total abundance (sum of three bags) of taxonomic groups associated with leaves of alder, poplar and mixture decomposing in the stream and at the riparian zone of Ribeira do Botão after 14 and 28 days. Taxa assigned to the group of the detritivores were the Isopoda, Collembola, Diplura, Leuctridae (Plecoptera), Lepidostomatidae and Sericostomatidae (Trichoptera) and Tipulidae (Diptera).

\begin{tabular}{|c|c|c|c|c|c|c|c|}
\hline \multirow[b]{2}{*}{ Location } & \multirow[b]{2}{*}{ Taxon } & \multicolumn{2}{|c|}{ Alder } & \multicolumn{2}{|c|}{ Poplar } & \multicolumn{2}{|c|}{ Mixture } \\
\hline & & day 14 & day 28 & day 14 & day 28 & day 14 & day 28 \\
\hline \multirow[t]{17}{*}{ Riparian } & Oligochaeta & & 2 & & 3 & 1 & 6 \\
\hline & Gastropoda & 4 & 6 & 1 & 6 & 2 & 8 \\
\hline & Chilopoda & & 1 & & & 1 & \\
\hline & Diplopoda & & 1 & & & & \\
\hline & Isopoda & 1 & & & & 5 & 2 \\
\hline & Acarina & & & & 1 & & 2 \\
\hline & Araneae & 2 & & & & & 2 \\
\hline & Opiliones & 3 & & & & & \\
\hline & Pseudoscorpionidae & 3 & & & 1 & 6 & 2 \\
\hline & Collembola & 2 & 17 & 1 & 28 & 10 & 35 \\
\hline & Diplura & & 1 & & & & \\
\hline & Hymenoptera & & 1 & & 1 & & \\
\hline & Coleoptera & 1 & & & 1 & & 1 \\
\hline & Trichoptera & & & & & & 1 \\
\hline & Diptera & 2 & 46 & 2 & 16 & 5 & 21 \\
\hline & Pupae & & 4 & & 2 & & \\
\hline & Total & 18 & 79 & 4 & 59 & 30 & 80 \\
\hline \multirow[t]{14}{*}{ Stream } & Nematoda & 1 & 1 & & & 1 & \\
\hline & Tricladida & 2 & 4 & & & & 1 \\
\hline & Hirudinea & 1 & & & & & \\
\hline & Gastropoda & 2 & & 3 & & 1 & \\
\hline & Hydracarina & & 5 & & & 1 & 7 \\
\hline & Collembola & & & & & & 1 \\
\hline & Ephemeroptera & & & & 3 & & \\
\hline & Plecoptera & 65 & 166 & 66 & 135 & 80 & 228 \\
\hline & Odonata & & 4 & & & 3 & 2 \\
\hline & Coleoptera & 2 & & & 3 & 1 & \\
\hline & Trichoptera & 8 & 19 & 5 & 10 & 14 & 15 \\
\hline & Diptera & 32 & 47 & 32 & 49 & 27 & 64 \\
\hline & Pupae & 4 & 2 & 2 & 4 & 4 & 5 \\
\hline & Total & 117 & 248 & 108 & 204 & 132 & 323 \\
\hline
\end{tabular}

zone. In fact, the most abundant taxonomic group of the stream communities, constituting at least $63 \%$ of all invertebrate abundance, were the stoneflies Leuctridae, and it is thus expected that leaf consumption by these efficient shredders likely contributed to the higher rates of leaf breakdown in the stream than at the riparian zone (Hutchens Jr. and Wallace, 2002). Additionally, abiotic factors, such as the effect of current velocity and sediment abrasion in the stream (Abelho, 2008), help explain the faster breakdown rates in the stream in comparison to the riparian zone.

Notwithstanding, breakdown rates $\left(k\right.$ day $\left.^{-1}\right)$ at the riparian area were medium (poplar: -0.0091) to fast (mixture: -0.0146, alder: -0.0187; Petersen and Cummins, 1974) and much faster than the breakdown rates of several species obtained in other decomposition studies at riparian areas, some of which include nitrogen-fixing species (Table 3). Moreover, in the present study stream rates were only 2 times faster than riparian rates and this ratio was consistent in all three litter types while other studies reported stream rates to be at least 3 to 9 times faster than riparian rates (Harner et al., 2009; Hutchens Jr. and Wallace, 2002).

Although decomposition was slower at the riparian zone than in stream, there was considerable mass loss of riparian leaves during the first 14 days (19.5-26.4\%) and the 28 days of the experiment $(22.5-40.7 \%)$. In temperate regions, lateral movements of riparian leaf fall to streams may represent $7-55 \%$ of direct fall (Abelho, 2001) but can be as high as $81 \%$ of total leaf litter entering streams (Benfield, 1997). If these riparian leaves are retained long enough at the riparian area before being blown or washed into the stream, they may be already in an advanced state of decomposition, that is, with only the more recalcitrant composts remaining. 
Table 3. Fastest breakdown rates of leaf litter obtained in several studies at riparian areas.

\begin{tabular}{llll}
\hline Fastest rate $\left(k\right.$ day $\left.^{-1}\right)$ & Leaf litter & Exposure & Reference \\
\hline-0.0012 & Herbaceous & Soil surface & Hefting et al. (2005) \\
-0.0017 & Red alder (Alnus rubra) & Soil surface & Matkins et al. (2004) \\
-0.0023 & Red alder (A. rubra) & Soil surface & Edmonds and Tuttle (2010) \\
-0.0035 & Cottonwood (Populus fremontii ssp. fremontii) $)$ & Soil surface & Borders et al. (2006) \\
-0.0044 & Red maple (Acer rubrum) & Soil surface & Hutchens Jr. and Wallace (2002) \\
-0.0072 & Russian olive (Elaeagnus angustifolia) & Soil subsurface $(10 \mathrm{~cm})$ & Harner et al. (2009) \\
\hline
\end{tabular}
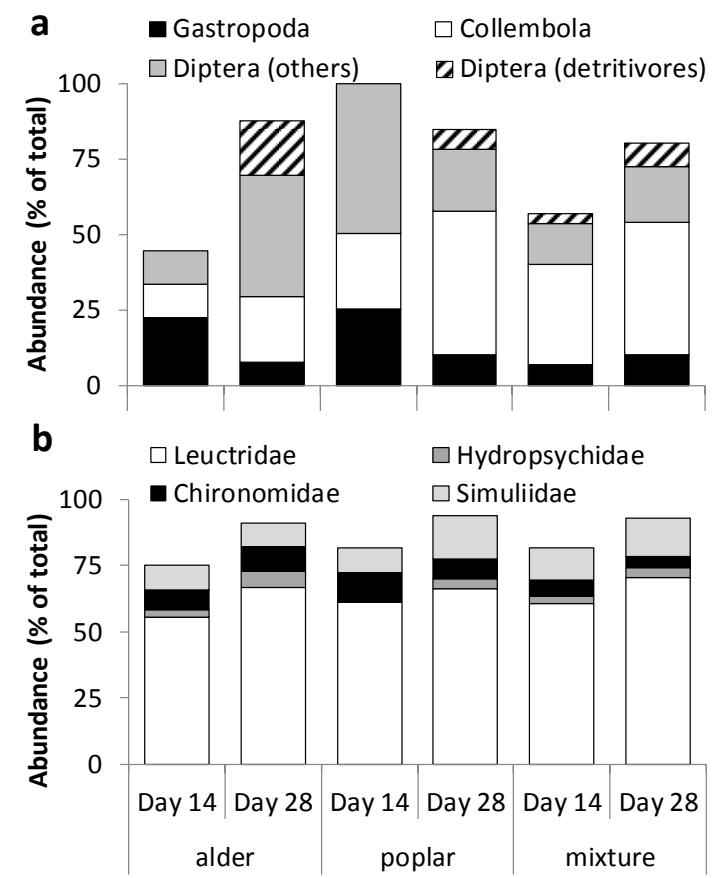

Figure 3. Relative abundance of the three most abundant taxonomic groups colonising leaves of alder, poplar and mixture decomposing (a) at the riparian zone and (b) in the stream of Ribeira do Botão. Detritivores are shown in white and stripes.

The breakdown rates of alder $\left(k=-0.0430 \mathrm{day}^{-1}\right)$ and poplar $\left(k=-0.0220 \mathrm{day}^{-1}\right)$ decomposing in the stream were fast according to the classification of Petersen and Cummins (1974). Decomposition rate of alder was similar to rates previously obtained in the same stream (Abelho, 2009; Gonçalves and Canhoto, 2009) and faster than most values reported in literature for the same or similar leaf species (e.g. Abelho, 2001; Canhoto and Graça, 1996). Decomposition rate of poplar was within the highest values reported for several species of poplar $\left(k=-0.0057\right.$ to $k=-0.0374$ day $\left.^{-1}\right)$ (Abelho, 2001; Casas et al., 2000; Harner et al., 2009).

Most studies consider alder to be a better food resource for both fungi and invertebrates when compared with other species (Canhoto and Graça, 1996; Gonçalves and Canhoto, 2009). In the present study, alder decomposed 2 times faster than poplar both in the stream and at the riparian zone, de- spite the higher abundance of Collembola in poplar leaves ( $48 \%$ versus $20 \%$ of total abundance). Although springtails are tiny when compared to other detritus-consuming invertebrates, their feeding activities may increase bacteria and reduce fungi thus exerting a strong differential effect on fungal and bacterial communities during decomposition (Hanlon and Anderson, 1979; Hopkin, 2002), and may contribute to the decomposition process of high and low quality litter (Yang et al., 2012). This could partially explain the lower fungal colonisation of poplar leaves and the difference in breakdown rates between alder and poplar at the riparian zone.

In the stream, ergosterol concentrations associated with poplar leaves attained higher values earlier in time and along the decomposition continuum than alder's, but invertebrate colonisation was higher in alder, both in terms of abundance and biomass, than in poplar leaves and partially explain the differences between the two species. Moreover, the enhancement of the breakdown of softer leaves by current velocity has been previously shown by several authors (Abelho, 2008; Casas et al., 2000; Chauvet, 1997), additionally explaining the differences in breakdown rate of alder and poplar in the stream.

\subsection{The effect of mixtures}

The effect of mixing litter on decomposition may be additive (e.g. Abelho, 2009; Taylor et al., 2007) but most commonly litter mixtures have been found to decompose at a different rate from their individual counterparts, showing either enhancement (Kominoski et al., 2007; Leroy and Marks, 2006), slowing of the processing rates (Taylor et al., 2007), or both, depending on the leaf species present in the mixture (Gonçalves and Canhoto, 2009). In the present study, the three methods resulted in different effects of mixing litter on the response variables. While the comparison of observed with expected values by ANOVA resulted in pure additive effects for all variables except for invertebrate abundance, the other two methods detected non-additive effects of mixing litter for most of the response variables. Differential results among methods were also found elsewhere (Ball et al., 2008; Kominoski et al., 2007).

Given the greater $N$ content of alder leaves and previous work with litter varying in quality (e.g. Ball et al., 2008; 

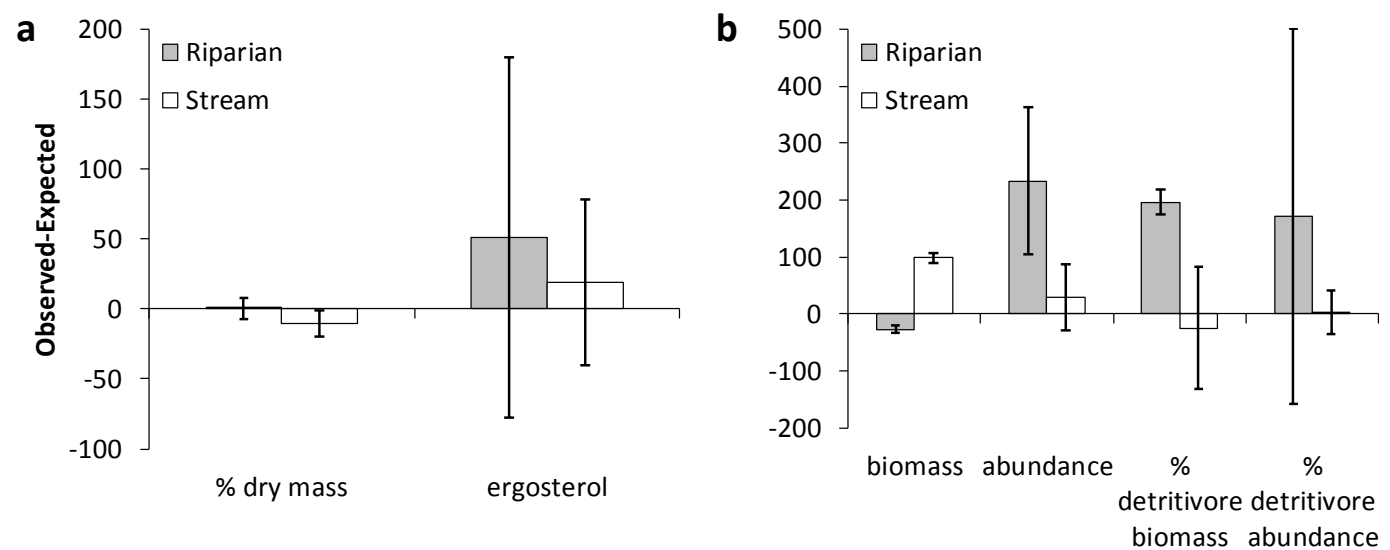

Figure 4. Difference between observed (mixture) and expected (average of single-species) values of (a) dry mass and ergosterol concentrations, and (b) invertebrate colonisation, calculated as $100 \times($ (observed - expected)/expected). Values are means of all samples $\pm 95 \%$ confidence intervals $(n=6)$. Mixtures are considered non-additive for a given variable when the CI bar does not cross the $y=0$ line.

Hättenschwiler and Gasser, 2005), we would expect nonadditive effects of mixing litter on decomposition. The comparison between dry mass remaining of a species in mixture with that species alone clearly detected synergistic effects of mixture on decomposition, with lower mass remaining (faster decomposition) of both alder and poplar in mixture than alone. However, according to method 3, this synergistic effect occurred only in the stream and not at the riparian area. Although there was an overall enhancement of the breakdown rate of individual leaf species in mixture, alder decomposed only 1.1 to 1.2 times faster while poplar decomposed 1.4 to 1.6 faster in the mixture than alone. Other experiments in the same stream have shown a decrease (alder $\times$ Spanish oak; Abelho, 2009) or an increase (alder $\times$ eucalypt; Gonçalves and Canhoto, 2009) in alder breakdown rates in mixtures, but those experiments were carried out with leaf species rich in deterrent compounds. The enhancement of poplar breakdown rates could be related to $\mathrm{N}$-transfer from alder to poplar (Schimel and Hättenschwiler, 2007).

Other studies have shown that, similarly to decomposition, mixing litter may have additive effects on invertebrate colonisation (Smith and Bradford, 2003), but in most cases, non-additive effects of mixtures on invertebrate colonisation have been found, attributed, for instance, to the deterrent physical effect of the slow-decomposing species in the access of invertebrates to the more palatable components of the mixture (Taylor et al., 2007) or to the preference of macroinvertebrates for one type of litter (Gonçalves and Canhoto, 2009). In the present study, mixing litter showed non-additive effects on invertebrate abundance and biomass, and, according to method 3, the effect of mixtures on invertebrate colonisation differed in the stream and at the riparian zone. Invertebrate abundance and percentage detritivore biomass were additive in the stream; at the riparian area mixing litter showed synergistic effects on invertebrate abundance and percentage detritivore biomass, suggesting that the more complex habitat provided by the mixtures was attractive for the invertebrates (Abelho, 2009), despite the lower amount of alder present in the mixture.

In the present study, the effect of mixing litter on the response variables depended on the method used to assess the existence of non-additive effects. The comparison of mixtures with the average of single species was the most conservative method, detecting non-additive effects on macroinvertebrate abundance only; the comparison of a species in mixture with that species alone detected non-additive effects on both dry mass remaining and ergosterol, with differential responses of both leaf species and habitat; the graphical analysis of the average difference between observed and expected values and the $95 \%$ confidence intervals not only detected non-additive effects on all variables except ergosterol and percentage detritivore abundance but also identified different responses of the leaves exposed in the terrestrial and the aquatic habitats. Thus, in addition to the influence of the experimental set-up (Hättenschwiler et al., 2005), the outcome of the studies on the effect of mixtures - including differential responses of terrestrial and aquatic habitats - also depends on the method used to detect non-additive effects.

Differential responses of the terrestrial and the aquatic habitat obtained in the present study may have a significant ecological meaning. In contrast to the suggestion by Gessner et al. (2010) that detritivores mediate litter-diversity effects on decomposition in both forest floors and streams, invertebrate colonisation at the riparian zone was non-additive showing that mixtures were colonised by more but smaller invertebrates than single species, but it was additive in the stream. On the other hand, decomposition was additive at the riparian area but synergistic in the stream. Thus, the higher invertebrate abundance of mixtures at the riparian zone did not translate into higher mass loss suggesting that the more 
complex habitat provided by the mixtures was probably used as shelter.

In conclusion, although the results provide an indication that the effects of mixing litter may be different in aquatic and terrestrial ecosystems this small-scale experiment does not allow meaningful generalisations of the results. The findings of the present work should be assessed in a larger-scale experiment in order to generalise the effects of mixing litter on terrestrial and aquatic habitats.

Acknowledgements. The author thanks Jorge Farias dos Santos for field and laboratory assistance and IMAR-CMA (University of Coimbra) for the HPLC analyses. Three anonymous referees provided constructive comments on previous versions of the manuscript.

Edited by: J. Stadler

Reviewed by: two anonymous referees

\section{References}

Abelho, M.: From litterfall to breakdown in streams: a review, TheScientificWorld, 1, 656-680, 2001.

Abelho, M.: Effects of leaf litter species on macroinvertebrate colonization during decomposition in a Portuguese stream, Int. Rev. Hydrobiol., 93, 358-371, 2008.

Abelho, M.: Leaf-litter mixtures affect breakdown and macroinvertebrate colonization rates in a stream ecosystem, Int. Rev. Hydrobiol., 94, 436-451, 2009.

Arizpe, D., Mendes, A., and Rabaça, J. E.: Sustainable riparian zones: a management guide, Generalitat Valenciana, Valencia, Spain, 2008.

Ball, B. A., Hunter, M. D., Kominoski, J. S., Swan, C. M., and Bradford, M. A.: Consequences of non-random species loss for decomposition dynamics: experimental evidence for additive and non-additive effects, J. Ecol., 96, 303-313, 2008.

Benfield, E. F.: Comparison of litterfall input to streams, J. N. Am. Benthol. Soc., 16, 104-108, 1997.

Borders, B. D., Pushnik, J. C., and Wood, D. M.: Comparison of leaf litter decomposition rates in restored and mature riparian forests on the Sacramento River, California, Restor. Ecol., 14, 308-315, 2006.

Canhoto, C. and Graça, M. A. S.: Decomposition of Eucalyptus globulus leaves and three native leaf species (Alnus glutinosa, Castanea sativa and Quercus faginea) in a Portuguese low order stream, Hydrobiologia, 333, 79-85, 1996.

Casas, J. J., Zamora-Muñoz, C., Archila, F., and Alba-Tercedor, J.: The effect of a headwater dam on the use of leaf bags by invertebrate communities, Regul. Rivers Res. Manage., 16, 577-591, 2000.

Chauvet, E.: Leaf litter decomposition in large rivers: the case of the River Garonne, Limnetica, 13, 65-70, 1997.

Cummins, K. W.: Riparian-stream linkage paradigm, Verh. Internat. Verein Limnol., 28, 49-58, 2002.

Edmonds, R. L. and Tuttle, K. M.: Red alder leaf decomposition and nutrient release in alder and conifer riparian patches in western Washington, USA, Forest Ecol. Manag., 259, 2375-2381, 2010.
Fior, R. C., Soares, M. R., and Casagrande, J. C.: Nutrient input through litter in riparian forest in different stages of ecological succession, 19th World Congress of Soil Science, Soil Solutions for a Changing World (1-6 August, Brisbane, Australia, Published on DVD), 67-70, 2010.

Gartner, T. B. and Cardon, Z. G.: Decomposition dynamics in mixed-species leaf litter, Oikos, 104, 230-246, 2004.

Gessner, M. O.: Ergosterol as a measure of fungal biomass, in: Methods to study litter decomposition: A practical guide, edited by: Graça, M. A. S., Bärlocher, F., and Gessner, M. O., Springer, Berlin, Germany, 171-176, 2005.

Gessner, M. O. and Chauvet, E.: Growth and production of aquatic hyphomycetes in decomposing leaf litter, Limnol. Oceanogr., 42, 496-595, 1997.

Gessner, M. O., Swan, C. M., Dang, C. K., McKie, B. G., Bardgett, R. D., Wall, D. H., and Hättenschwiler, S.: Diversity meets decomposition, Trends Ecol. Evol., 25, 372-380, 2010.

Gonçalves, A. L. and Canhoto, C.: Decomposition of eucalypt and alder mixtures: responses to variation in evenness, Fund. Appl. Limnol., 173, 293-303, 2009.

Hanlon, R. D. G. and Anderson, J. M.: The effects of collembola grazing on microbial activity in decomposing leaf litter, Oecologia, 38, 93-99, 1979.

Harner, M. J., Crenshaw, C. L., Abelho, M., Stursova, M., FollstadShah, J. J., and Sinsabaugh, R. L.: Decomposition of leaf litter from a native tree and an actinorhizal invasive across riparian habitats, Ecol. Appl., 19, 1135-1146, 2009.

Hättenschwiler, S. and Gasser, P.: Soil animals alter plant litter diversity effects on decomposition, P. Natl. Acad. Sci. USA, 102, 1519-1524, 2005.

Hättenschwiler, S., Tiunov, A. V., and Scheu, S.: Biodiversity and litter decomposition in terrestrial ecosystems, Annu. Rev. Ecol. Evol. S., 36, 191-218, 2005.

Hefting, M. M., Clement, J.-C., Bienkowski, P., Dowrick, D., Guenat, C., Butturini, A., Topa, S., Pinay, G., and Verhoevenet, J. T. A.: The role of vegetation and litter in the nitrogen dynamics of riparian buffer zones in Europe, Ecol. Eng., 24, 465-482, 2005.

Hopkin, S. P.: Collembola, in: Encyclopaedia of Soil Science, edited by: Lal, R., Marcel Dekker, New York, USA, 207-210, 2002.

Hunter, M. D., Adi, S., Pringle, C. M., and Coleman, D. C.: Relative effects of macroinvertebrates and habitat on the chemistry of litter during decomposition, Pedobiologia, 47, 101-115, 2003.

Hutchens Jr., J. J. and Wallace, J. B.: Ecosystem linkages between Southern Appalachian headwater streams and their banks: leaf litter breakdown and invertebrate assemblages, Ecosystems, 5, 80-91, 2002.

Kominoski, J. S., Pringle, C. M., Ball, B. A., Bradford, M. A., Coleman, D. C., Hall, D. B., and Hunter, M. D.: Nonadditive effects of leaf litter species diversity on breakdown dynamics in a detritusbased stream, Ecology, 88, 1167-1176, 2007.

Kominoski, J. S., Hoellein, T. J., Leroy, C. J., Pringle, C. M., and Swan, C. M.: Beyond species richness: expanding biodiversityecosystem functioning theory in detritus-based streams, River Res. Appl., 24, 1-9, 2009.

Lecerf, A., Risnoveanu, G., Popescu, C., Gessner, M. O., and Chauvet, E.: Decomposition of diverse litter mixtures in streams, Ecology, 88, 219-227, 2007. 
Leroy, C. J. and Marks, J. C.: Litter quality, stream characteristics and litter diversity influence decomposition rates and macroinvertebrates, Freshwater Biol., 51, 605-617, 2006.

Leuven, R. S. E. W., Brock, T. C. M., and van Druten, H. A. M.: Effects of preservation on dry- and ash-free dry weight biomass of some common aquatic macro-invertebrates, Hydrobiologia, 127, 151-159, 1985.

Matkins, J., Hibbs, D. E., and Perakis, S.: Litter decay in coast range riparian zones: biogeochemical controls and implications for terrestrial and aquatic food chains, in: Annual Report 2004, edited by: Erickson, J., Cooperative Forest Ecosystem Research Program, Corvallis, USA, 85-87, 2004.

Naiman, R. J. and Décamps, H: The ecology of interfaces: riparian zones, Annu. Rev. Ecol. Syst., 28, 621-658, 1997.

Newell, S. Y.: Estimating fungal biomass and productivity in decomposing litter, in: The fungal community: its organization and role in the ecosystem, 2nd, edited by: Carroll, G. C. and Wicklow, D. T., Marcel Dekker, New York, USA, 521-561, 1992.

Petersen, R. C. and Cummins, K. W.: Leaf processing in a woodland stream, Freshwater Biol., 4, 343-368, 1974.

Quigley, M. and Madge, D.: Land invertebrates, Basil Blackwell, Oxford, UK, 1988.
Schimel, J. P. and Hättenschwiler, S.: Nitrogen transfer between decomposing leaves of different N status, Soil Biol. Biochem., 39, 1428-1436, 2007.

Smith, V. C. and Bradford, M. A.: Do non-additive effects on decomposition in litter-mix experiments result from differences in resource quality between litters?, Oikos, 102, 235-242, 2003.

Tachet, H., Richoux, P., Bournaud, M., and Usseglio-Polatera, P.: Invertébrés d'eau douce - systématique, biologie, écologie, CNRS Éditions, Paris, France, 2000.

Taylor, B. R., Mallaley, C., and Cairns, J. F.: Limited evidence that mixing leaf litter accelerates decomposition or increases diversity of decomposers in streams of eastern Canada, Hydrobiologia, 592, 405-422, 2007.

Yang, X., Yang, Z., Warren, M. W., and Chen, J.: Mechanical fragmentation enhances the contribution of Collembola to leaf litter decomposition, Eur. J. Soil Biol., 53, 23-31, 2012.

Young, J. C.: Microwave-assisted extraction of the fungal metabolite ergosterol and total fatty acids, J. Agr. Food Chem., 43, 2904-2910, 1995.

Zar, J. H.: Biostatistical analysis, 3rd Edn., Prentice-Hall International, Inc., Upper Saddle River, 1996. 